\title{
DIPLOMASI KOMERSIAL JEPANG KE INDONESIA MELALUI PERUSAHAAN MULTINASIONAL JEPANG DI INDONESIA
}

\author{
Sindy Yulia Putri \\ Prodi Hubungan Internasional \\ Universitas Pembangunan Nasional Veteran Jakarta \\ Email: sindyyulia@upnvj.ac.id
}

\begin{abstract}
ABSTRAK
Lebih dari setengah abad kemitraan Jepang dan Indonesia sudah dijalin kedua belah pihak. Selama rentang waktu tersebut, berbagai strategi diplomasi telah diimplementasikan Jepang dalam menjalin kemitraan dengan Indonesia. Tulisan ini akan menganalisis diplomasi komersial Jepang ke Indonesia dalam memperkuat eksistensi perusahaan miultinasionalnya di Indonesia. Topik ini diangkat, karena liberalisasi perdagangan dan pembangunan berkaitan erat dengan peran negara dan MNC. Tulisan ini menggunakan pendekatan kualitatif deskriptif dengan studi literatur sebagai teknik pengumpulan data. Analisis dari tulisan ini akan menggunakan teori diplomasi komersial. Teori ini cukup komprehensif menerangkan mengenai berbagai aktivitas diplomasi komersial yang mencakup aktivitas perdagangan, investasi, dan pergerakan perusahaan dengan dorongan negara. Melalui proses analisis dan interpretasi data, maka hasil penelitian ini adalah Jepang berupaya mempertahankan eksistensinya sebagai mitra dagang dan bisnis melalui operasionalisasi berbagai perusahaan multinasionalnya di Indonesia. Multinational Corporation (MNC) Jepang menjalin kemitraan dengan berbagai pemangku kepentingan, mulai dari pelaku usaha di Indonesia hingga akademisi. Hasil penelitian ini penting untuk menjadi acuan penelitian selanjutnya seputar diplomasi komersial.
\end{abstract}

Kata kunci: Diplomasi Komersial; Jepang; Indonesia; Perusahaan Multinasional

\begin{abstract}
More than half a century of partnership between Japan and Indonesia have been established by both parties. During this time, various diplomatic strategies have been implemented by Japan in establishing partnership with Indonesia. This paper will analyze Japanese commercial diplomacy to Indonesia in strengthening the existence of its multinational corporation (MNC) in Indonesia. This topic is raised, because trade liberalization and development are closely related to the role of state and MNC. This paper have used a descriptive qualitative approach with literature study as a data collection technique. The analysis of this paper used the commercial diplomacy theory. This theory is quite comprehensive explaining the various commercial diplomacy activities including trade, investment, and company movement with the state encouragement. Through the process of data analysis and interpretation, the results of this study are that Japan seeks to maintain its existence as a crucial trading and business partner through the operationalization of various MNCs in Indonesia. Japan's MNCs have established partnerships with various stakeholders, ranging from businesses to academics in Indonesia. The results of this study are important to be a reference for further research
\end{abstract}


around commercial diplomacy.

Keywords: Commercial Diplomacy; Japan; Indonesia; Multinational Corporation

\section{PENDAHULUAN}

Keberhasilan Jepang di percaturan dunia internasional tidak terlepas dari upaya diplomasi yang telah dibangun Jepang selama ini. Jepang telah membuktikan, bahwa Asia Timur dapat menjadi bagian krusial dalam konstelasi ekonomi dan politik di tingkat internasional. Jepang dapat berkolaborasi dengan berbagai negara terutama Indonesia, baik dalam relasi government to government atau " $\mathrm{G}$ to $\mathrm{G}$ " maupun government to business atau "G to B". Jepang juga melebarkan sayap diplomasinya untuk mengukuhkan eksistensi perusahaan multinasional (MNC) Jepang ke berbagai negara termasuk Indonesia. Perusahaan Jepang yang disebut dalam bahasa Jepang sebagai sogo shosha telah memberikan bukti nyata untuk terlibat dalam pasar global. Komunitas internasional mengakui kapasitas dan kredibilitas perusahaan Jepang untuk memproduksi dan mengekspor produk-produk berkualitas tinggi, seperti elektronik (SONY, Toshiba, Hitachi), kendaraan (Sumitomo Metal, Toyota Tsusho, Mitsubishi Motors, Suzuki, Mitsui), instrumen medis, farmasi, produk kecantikan (Shiseido dan Kanebo Twany), dan seterusnya (Anwar, 2018).

Diplomasi yang dilakukan Jepang lebih berorientasi diplomasi komersial, karena sebagian besar diimplementasikan pada transaksi perdagangan dan mobilisasi perusahaan nasional di Indonesia. Sabaruddin (2018) menelaah, bahwa terdapat beberapa strategi diplomasi yang dilakukan oleh negara-negara anggota OECD termasuk Jepang meliputi volume perdagangan, volume foreign direct investment (FDI), dan volume wisatawan mancanegara. Ketiga hal tersebut kerap disebut dengan aktivitas trade, tourism, investment (TTI). Selanjutnya, JICA (2018) mencermati, bahwa hubungan bilateral antara Jepang dan Indonesia memberikan manfaat untuk kedua belah pihak. Presiden Joko Widodo menitikberatkan pada pengembangan infrastruktur sebagai kebijakan dalam negeri di Kabinet Indonesia Maju (RPJMN Bappenas, 2020). Menilik kebijakan dalam negeri Indonesia, Jepang hadir dengan memobilisasi berbagai perusahaannya untuk mempererat kemitraan dengan Indonesia dan sekaligus memperkuat eksistensinya di Indonesia. Mengacu pada latar belakang di atas, maka kajian mengenai diplomasi komersial menjadi penting untuk diteliti. Tulisan ini akan mengelaborasi lebih dalam mengenai instrumen diplomasi Jepang ke Indonesia melalui berbagai aktivitas perusahaan multinasional Jepang 
di Indonesia.

\section{PEMBAHASAN}

Tulisan ini akan ditelaah dari teori diplomasi komersial. Tulisan ini juga merupakan hasil penelitian dengan menggunakan pendekatan kualitatif bersifat deskriptif dan pengumpulan data dilakukan dengan studi literatur. Diplomasi komersial pada dasarnya merupakan irisan dari diplomasi perdagangan dan diplomasi finansial. Diplomasi komersial bergerak di serangkaian kegiatan untuk mempromosikan dan memfasilitasi bisnis internasional. Naray (2007) membedakan beberapa jenis aktivitas diplomasi komersial, yakni komunikasi, advokasi, koordinasi, dan logistik. Keduanya berargumen, bahwa berbagai aktivitas tersebut dikorelasikan dengan bidang-bidang tertentu, seperti akses pasar untuk intensitas perdagangan dan hak kekayaan intelektual. Diplomasi komersial juga kerap diterpkan untuk membangun citra negara yang bernegosiasi, dukungan ekspor, pemasaran, riset, dan publikasi. Kemudian Lee (2004) mencermati, bahwa diplomasi komersial dimanfaatkan untuk menghasilkan keuntungan komersial tertentu melalui promosi ekspor-impor, menarik investasi, dan mendorong manfaat transfer teknologi. Sejalan dengan beberapa pendapat sebelumnya, Ruél et al (2012) dari Netherlands Institute of International Relations Clingendael lebih elaboratif lagi dalam mengkaji diplomasi komersial. Ruél dan rekannya menilai, diplomasi komersial semakin krusial bagi negara-negara maju untuk memperkuat pengaruh ekonomi-politik domestik di negara mitra dan sekaligus menyempurnakan keterlibatannya di tatanan ekonomi-politik global. Terlebih lagi hingga beberapa tahun mendatang, perhatian dunia akan semakin bergeser ke negara-negara kawasan timur. Bagi negara maju, negara-negara mitra merupakan jantung dari diplomasi komersial dan memberikan dukungan yang efektif untuk aktivitas bisnis home country di host country. Kesiapan home country dan host country melalui perbaikan tata kelola institusi kedua negara juga dinilai penting untuk optimalisasi diplomasi komersial. Diplomat komersial - dalam kasus ini adalah pengusaha - harus memahami secara holistik kapasitas negara eksportir dan importir, sehingga dapat mengimplementasikan pendekatan bisnis yang lebih efektif.

Mengacu pada teori diplomasi komersial yang dikemukakan oleh para ahli sebelumnya, maka relokasi perusahaan Jepang ke Indonesia didukung oleh Pemerintah Jepang. Operasionalisasi perusahaan Jepang di Indonesia tidak terlepas dari peran state actor. Yang menarik dari diplomasi komersial Jepang adalah hubungan segitiga/triangular antara Pemerintah Jepang, MNC Jepang, dan Pemerintah Indonesia. Jepang telah 
memperoleh "hati” Indonesia sejak lama, sehingga tidak sulit bagi MNC Jepang untuk penetrasi pasar di host country Indonesia, dari kegiatan bisnis, perdagangan, investasi, hingga jalinan kemitraan dengan akademisi di Indonesia. Diplomasi komersial Jepang merepresentasikan adanya simbiosis mutualisme antara state actor dan non-state actor. MNC tidak menafikan negara dan negara juga mendorong kemajuan MNC.

Di era revolusi industri 4.0, Jepang semakin mendorong berbagai perusahaan domestiknya untuk berinovasi melalui teknologi, namun tetap memperhatikan sustainable development goals (SDGs) dan human literacy. Bahkan Jepang sendiri telah meneliti, bahwa dunia akan memasuki era revolusi industri 5.0. Keidanren atau Federasi Bisnis Jepang merevisi Charter of Corporate Behavior. Revisi tersebut meregulasi perilaku penguasaha yang seharusnya dapat lebih berorientasi pada pembangunan berkelanjutan dan membentuk masyarakat yang sejahtera dengan mengacu pada 17 target SDGs. Revolusi industri 4.0 dan 5.0 nantinya seharusnya mampu membentuk wadah yang nyaman bagi masyarakat untuk menikmati hidup sepenuhnya. Pertumbuhan ekonomi dan perkembangan teknologi bukan untuk segelintir orang. Sesuai dengan konsep tersebut, Pemerintah Jepang telah mendorong epistemic community dan dunia industri untuk memanfaatkan teknologi dalam menyelesaikan masalah sosial demi mewujudkan keadilan dan kesejahteraan sosial di suatu negara (Fukuyama, 2018).

Atas dasar revolusi industri tersebut, Pemerintah Jepang mendorong kemitraan antara pengusaha Jepang dengan berbagai negara mitra, termasuk Indonesia. Hingga akhir tahun 2019, Jepang merupakan negara destinasi ekspor terbesar ketiga bagi Indonesia, sementara Indonesia merupakan negara sumber impor kesembilan bagi Jepang. Indonesia juga mengimpor beberapa produk unggulan Jepang mencakup mobil, kendaraan bermotor, suku cadang, peralatan otomotif motor dan mobil, mesin cetak, dan sebagainya. Sementara untuk aktivitas ekspor Indonesia ke Jepang didominasi oleh minyak, gas, hidrokarbon, batubara, produk olahan batubara, bijih besi dan tembaga, bahan bakar mineral, logam mulia, karet, kawat berinsulasi, alas kaki, ikan, dan produk olahan ikan (Kementerian Perdagangan RI, 2020). Perdagangan Indonesia-Jepang di tahun 2017 saja sudah mencapai USD 33 miliar. Ekspor sebesar USD 17.8 miliar, impor sebesar USD 15.2 miliar dan surplus USD 2.5 miliar. Jepang juga menjadi salah satu investor terbesar Indonesia. Hingga September 2017, Jepang merupakan sumber FDI terbesar kedua dengan persentase sebesar $13.3 \%$ dari total FDI di Indonesia atau sebesar USD 4.9 miliar dengan sektor utama investasi yakni sektor industri alat angkut dan transportasi, otomotif, listrik, gas, air, industri logam, mesin, dan elektronik (Wibisono, 2020). Kemudian menjelang tahun 2019, 
Jepang berhasil merealisasikan proyek megastruktur Mass Rapid Transit (MRT) Jakarta dengan skema konsorsium dan melibatkan sebagian besar perusahaan multinasional di bidang konstruksi, seperti Obayashi, Shimizu, dan Tokyu. Perusahaan-perusahaan tersebut menggandeng beberapa perusahaan konstruksi Indonesia, seperti PT Hutama Karya (Persero), PT Wijaya Karya Tbk (WIKA), dan PT Jaya Konstruksi Tbk. MRT fase 1 beroperasi dari stasiun Lebak Bulus hingga stasiun Bundaran Hotel Indonesia sepanjang $15.7 \mathrm{~km}$. Realisasi proyek MRT bertujuan mengurangi kemacetan di kota megapolitan Jakarta dan peningkatan fasilitas layanan di wilayah urban (JICA, 2018).

Sementara di bidang perdagangan, Indonesia-Japan Economic Partnership Agreement (IJEPA) dinilai memberikan kontribusi positif untuk menstimulus perdagangan Indonesia-Jepang. Berdasarkan data Kementerian Perdagangan RI (2020), terdapat beberapa manfaat yang diperoleh Indonesia dari kerangka kerjasama IJEPA yaitu:

\section{Meningkatkan akses pasar barang dan jasa}

IJEPA menghilangkan hambatan perdagangan dan meningkatkan impor Jepang dari Indonesia, baik untuk barang maupun sektor jasa. Dengan adanya IJEPA, para pelaku usaha/konsumen dapat memperoleh produk Jepang dengan tarif yang lebih rendah (preferensi). Di samping itu, Jepang juga membuka sektor jasanya untuk 12 sektor yakni jasa travel, transportasi, komunikasi, konstruksi, keuangan, komputer, dan sistem informasi.

\section{Meningkatkan investasi}

IJEPA akan meningkatkan nilai investasi Jepang khususnya pada industri manufaktur. Di IJEPA terdapat skema khusus yaitu User Specific Duty Free Scheme (USDFS). Skema ini merupakan pembebasan bea masuk yang diberikan Indonesia untuk produk bahan baku buatan Jepang yang digunakan dalam proses produksi industri Jepang yang beroperasi di Indonesia, seperti otomotif dan komponennya, alat listrik, elektronik, mesin konstruksi, dan peralatan sektor energi (alat berat untuk migas dan tenaga listrik).

\section{Membuka peluang kerja di Indonesia dan di Jepang}

IJEPA juga berkontribusi meningkatkan penanaman modal Jepang di sektor manufaktur Indonesia. PT Toyota Motor Manufacturing Indonesia (2020) misalnya, saat ini mempekerjakan lebih dari 7800 tenaga kerja Indonesia. Tidak hanya industri manufaktur, sektor kesehatan juga membutuhkan SDM terampil Indonesia. 
Mulai tahun 2008 hingga 2017 tercatat 622 orang tenaga perawat medis dan 1494 tenaga perawat lansia telah ditempatkan di Jepang.

\section{Meningkatkan Kerjasama Peningkatan Kapasitas}

IJEPA menyediakan skema capacity building melalui pelatihan dan keterampilan tenaga kerja dan juga membantu promosi ekspor produk-produk UKM. Skema tersebut dapat mendorong pertumbuhan industri UKM yang akan bermanfaat bagi perkembangan industri nasional Indonesia.

Meskipun pergerakan MNC atau sogo shosha terbilang sangat proaktif, namun pertumbuhan ekonomi global pasca krisis keuangan global yang menurun secara bertahap berimplikasi pada penurunan aktivitas operasional sogo shosha. Pertumbuhan GDP dunia diperkirakan hanya $2.6 \%$ pada tahun 2014. Perlambatan pertumbuhan ekonomi juga berdampak pada perekonomian Jepang secara keseluruhan. Tahun 2015 merupakan tahun pemulihan bagi Jepang. Berbagai perusahaan di Jepang mengalami hambatan untuk ekspansi pasar, sehingga pendapatan yang diterima juga mengalami penurunan. Perusahaan juga belum bisa meningkatkan upah pekerja secara signifikan, karena terbatasnya investasi untuk human capital pada saat itu (Mizushima, 2016). Ironisnya, perlambatan ekonomi terus terjadi hingga pandemi covid-19. Berbagai dampak negatif yang dipicu oleh covid-19 telah menurunkan kinerja ekonomi dunia di tahun 2020. Bank Indonesia memperkirakan pertumbuhan ekonomi dunia pada 2020 hanya sebesar $2.5 \%$, turun dibandingkan pertumbuhan 2019 sebesar 2.9\% (Christian et al, 2020).

Berbagai dinamika perekonomian di atas mendorong berbagai pemangku kepentingan di Jepang untuk menstimulus perusahaan agar lebih produktif. Stimulus tersebut dapat dioptimalkan melalui kegiatan inovasi dan penelitian. Inovasi muncul karena adanya dorongan kebutuhan organisasi dan perusahaan untuk beradaptasi dengan tuntutan perubahan yang terjadi di sekitarnya. Perubahan bisa dipicu oleh pergeseran selera dan preferensi pasar, peningkatan harapan dan daya beli masyarakat, pergeseran gaya hidup, peningkatan kesejahteraan, perkembangan ekonomi, pengaruh globalisasi, serta kemajuan ilmu pengetahuan dan teknologi. Inovasi lahir dari imajinasi pemikiran orangorang kreatif dan lahirnya kreativitas didorong oleh kemunculan ide/gagasan baru untuk ke luar dari rutinitas yang membosankan. Gagasan kreatif yang lahir dari hasil pemikiran individu akan mendorong munculnya berbagai prakarsa, sehingga dapat memperkaya program kerja dan memunculkan diferensiasi produk/jasa, seiring dengan berkembangnya tuntutan kebutuhan konsumen (Yuniarsih, 2015). 
Pemerintah Jepang berupaya menciptakan iklim yang kondusif di masa pemerintahan Perdana Menteri Shinzo Abe atau lazim dikenal dengan tren Abenomics. Tidak dapat dipungkiri, Jepang memiliki kapabilitas tinggi dalam memproduksi produkproduk berbasis teknologi dan internet of things (IoT). Bahkan Jepang memiliki Japan's IoT Acceleration Consortium (ITAC) yang mengakomodir berbagai sektor, mencakup keamanan siber, standardisasi internasional, standardisasi, reformasi peraturan internasional, dan dukungan untuk korporasi kecil maupun besar. Perkembangan teknologi yang masif di Jepang semakin mendorong perusahaan-perusahaan Jepang untuk mengembangkan inovasi baru melalui teknologi. Teknologi juga membantu Jepang menghasilkan sophisticated products. Perusahaan Jepang menghasilkan banyak produk unggulan yang dikenal di pasar internasional, seperti robot, jarum suntik terkecil di dunia, toilet hemat air, ramah lingkungan, bangunan tahan gempa, dan moda transportasi publik dari mulai sepeda hingga kereta cepat shinkansen. Tetapi di sisi lain, perusahaan Jepang harus mengidentifikasi lebih jeli dinamika pasar di Indonesia. Perusahaan Jepang dapat menghasilkan lebih banyak produk inovatif yang juga merupakan kebutuhan negara-negara di dunia. Berbagai produk berbasis high tech tersebut kerap diimpor oleh Cina, Korea Selatan, Eropa, Amerika Serikat, dan tentu saja Indonesia (JEITA, 2016).

Sebagian besar masyarakat Indonesia tertarik pada barang elektronik dan pakaian. Perusahaan Jepang dapat membuat produk dengan harga lebih terjangkau. Penulis mengkaji, bahwa Jepang dapat mempromosikan dan memanfaatkan e-commerce yang lebih optimal karena proliferasi gawai dalam beberapa tahun terakhir. Di era borderless ini, Jepang mungkin menargetkan pasar kaum muda dan kelas menengah baru di Asia Tenggara. Perusahaan Jepang dapat mengamati tren permintaan kelas menengah atau urban baru. Kebijakan ini akan menjadi titik penjualan yang baik bagi perusahaanperusahaan Jepang untuk meningkatkan kinerja dan produktivitas mereka, berkenaan dengan perilaku konsumtif Indonesia secara khusus dan Asia Tenggara pada umumnya. Data-data dari Bappenas menunjukkan, bahwa pada 2030-2040, Indonesia diprediksi akan mengalami masa bonus demografi, yakni jumlah penduduk usia produktif (berusia 15-64 tahun) lebih besar dibandingkan penduduk usia tidak produktif (berusia di bawah 15 tahun dan di atas 64 tahun). Pada periode tersebut, penduduk usia produktif diprediksi mencapai 64\% dari total jumlah penduduk yang diproyeksikan sebesar 297 juta jiwa (Afandi, 2017).

Pertumbuhan demografi di Indonesia selaras dengan peningkatan kuantitas masyarakat menengah atas di Indonesia. Peningkatan tersebut dipengaruhi transisi demografi Indonesia yang semakin didominasi generasi produktif usia muda serta 
perkembangan kelas menengah di era ekonomi digital. Hal ini terkait dengan tingkat keyakinan rumah tangga kelompok menengah sehingga berpengaruh terhadap konsumsi. Secara umum, keyakinan konsumen pada 2017 lebih baik dengan adanya optimisme terhadap prospek perbaikan ekonomi. Perubahan perilaku konsumen ditandai dengan konsumsi yang lebih rasional dan selektif serta pergeseran preferensi konsumsi ke arah leisure dan lifestyle. Pergeseran pola konsumsi tersebut terindikasi telah berlangsung dalam tiga tahun terakhir, didorong oleh perkembangan akses teknologi serta peningkatan daya beli terhadap jenis belanja yang bersifat leisure dan lifestyle (BI, 2017, p. 25)

Dinamika kelas demografi dan kelompok menengah atas di Indonesia menjadi peluang menarik bagi perusahaan Jepang untuk melakukan penetrasi pasar. Ada beberapa strategi dalam menjalankan bisnis, seperti product strategy, price strategy, distribution strategy, promotion strategy, process strategy, physical evidence strategy, and people strategy atau dikenal dengan 7P (Kartawinata et al, 2015). Sejauh ini, perusahaan Jepang memiliki strategi yang baik untuk menjalankan bisnis mereka. Berbagai produk Jepang telah diakui di seluruh dunia. Dunia sudah paham, bahwa produk Jepang memiliki kualitas tinggi. Jepang juga mendapatkan tempat untuk melakukan bisnis di berbagai negara. Asia Tenggara memasuki Masyarakat Ekonomi ASEAN. Melalui program ini, Asia Tenggara lebih terhubung dan terintegrasi intra-regional dan inter-regional termasuk dengan Jepang. Perusahaan Jepang memiliki peluang lebih besar untuk merelokasi bisnis mereka di Asia Tenggara. Selain itu, Jepang memperoleh peluang untuk penetrasi pasar dalam kerangka Masyarakat Ekonomi ASEAN (Sekretariat ASEAN, 2018).

Di sektor perdagangan, produk-produk Jepang juga diklasifikasikan memiliki harga yang sesuai dengan kualitas produk. Kualitas produk menjadi salah satu keunggulan produk Jepang di pasar domestik dan internasional. Perusahaan Jepang bisa lebih berinovasi melalui kegiatan promosi yang lebih atraktif untuk menarik minat konsumen. Cara ini penting, karena sebagian besar konsumen mengandalkan kesan pertama untuk membeli sesuatu. Konsumen akan lebih visual dalam menentukan pilihan. Mereka lebih mementingkan kemasan dan promosi yang menarik. Jika promosi produk Jepang lebih menarik dan produk-produknya lebih inovatif, maka Sogo Shosha dapat semakin meningkatkan daya saing dan eksistensi di pasar global. Inovasi produk dilakukan oleh perusahaan clothing e-commerce terbesar di Jepang yaitu Zozotown. Perusahaan tersebut memiliki aplikasi untuk mengukur proporsi tubuh konsumen. Pakaian yang dijual juga dirancang khusus. Perusahaan ini juga telah memiliki konsumen dari seluruh dunia, termasuk Indonesia. Jepang sendiri menganut sistem disruptive innovation dengan 
meningkatkan jumlah dan kualitas riset untuk mengetahui lebih komprehensif minat pasar dan cara untuk penetrasi pasar yang lebih optimal di Indonesia. Inovasi juga memanfaatkan sistem information, communication, and technology (ICT) yang sedang sangat maju di Jepang.

Sebagai bahan komparasi, Tokopedia, salah satu startup e-commerce terbesar dan tersukses di Indonesia, baru-baru ini kembali mendapatkan suntikan dana sebesar USD 147 juta dari SoftBank Internet and Media Inc (SIMI), perusahaan telekomunikasi dan media asal Jepang yang juga memimpin funding pada putaran pertama dengan investasi berjumlah USD 100 juta. Ini berarti jumlah total funding Tokopedia hingga kini berjumlah USD 247.7 juta, cukup untuk membuatnya masuk ke dalam kategori "Unicorn startup" dari Indonesia, atau startup yang berhasil menembus nilai valuasi pasar sebesar sedikitnya USD 100 juta (Oktober 2014). Industri kratif di Indonesia juga semakin berkomitmen dalam memajukan sektor industri di Indonesia melalui pembentukan Dana Ekonomi Kreatif (DEKRAF). DEKRAF sebagai wujud dukungan Badan Ekonomi Kreatif (BEKRAF) kepada para pelaku Ekonomi Kreatif (Ekraf) di 16 subsektor. DEKRAF menjadi komitmen pendanaan kepada pelaku Ekraf yang berwujud pinjaman, hibah, maupun investasi. Perusahaan-perusahaan Indonesia mengadakan Konferensi yang memperkenalkan perusahaan-perusahaan filantropis di Jepang untuk mendorong jaringan positif di ASEAN dalam membangun promosi budaya melalui pertukaran seni dan budaya (BEKRAF, 2017).

Selain perusahaan startup, perusahaan makanan juga tidak tinggal diam. Berbagai perusahaan makanan Jepang yang telah memiliki cabang atau anak perusahaan di Indonesia juga semakin bertransformasi menjadi perusahaan yang mampu bekerja sama dan meningkatkan daya saing anak perusahaan di Indonesia sebagai host country. Produk makanan olahan dan minuman di pasar Jepang memiliki turnover yang cukup tinggi yang ditandai dengan tren produk yang selalu berubah-ubah. Jepang memiliki tingkat inovasi yang yang tinggi bahkan pada produk makanan olahan dan minuman. Selain itu, konsumen di Jepang juga lebih tertarik pada makanan olahan yang instan dan mudah untuk disajikan. Produktivitas dan budaya kerja yang tinggi mendorong masyarakat Jepang memiliki sedikit waktu untuk melakukan aktivitas lain di luar pekerjaan. Oleh karena itu, sebagian besar masyarakat Jepang, khususnya di kota besar lebih memilih ready-to-eat meals. Sekitar tiga per empat impor protein nabati dipasok oleh Amerika Serikat. Selain memiliki pangsa yang besar, impor protein nabati dari Amerika Serikat juga masih meningkat rata-rata sebesar 2,9\% per tahun selama 2013-2017. Pemasok utama lainnya adalah Cina (pangsa 16,31\%); Australia (pangsa 3,17\%); Perancis (pangsa 2,15\%) dan Belanda (pangsa 1,23\%). 
Indonesia saat ini belum pernah memasok produk protein nabati ke pasar Jepang. Hal ini diperkirakan karena sebagian besar bubuk protein nabati berasal dari kedelai dimana produksi komoditas tersebut masih terbatas di Indonesia. Bahkan Indonesia sendiri masih bergantung pada impor kedelai. Namun Indonesia mengisi impor Jepang dari berbagai komoditas lain yang didominasi oleh campuran bahan makanan (pangsa 47,2\%), konnyaku (pangsa 33,4\%), edible fat dan minyak (pangsa 16,4\%). Impor edible fat dan minyak Jepang dari Indonesia cukup signifikan nilainya di tahun 2017. Indonesia masih memiliki peluang untuk melakukan diversifikasi produk cakupan lainnya yang masuk ke dalam HS 210690 seperti vitamin, campuran makanan non-alkohol untuk beverages dan suplemen makanan serta terus meningkatkan dan memperbesar pasar ekspor sirup ke pasar Jepang (ITPC Osaka, 2018).

Penulis menganalisis, selain optimalisasi inovasi, sogo shosha juga dapat mengembangkan berbagai penelitian/riset untuk ekspansi pasar di Indonesia. Penelitian menjadi tahapan penting untuk membaca bagaimana perusahaan dapat menarik perhatian konsumen dan bagaimana produk itu bisa dikenal secara global. Penelitian dapat dilakukan oleh perusahaan atau komunitas akademik. Dunia pendidikan mampu bersinergi dan berkolaborasi dengan dunia bisnis. Bisnis dan penelitian bisa menjadi cermin yang saling mencerminkan. Peneliti memberikan umpan balik tentang kondisi pasar global dan fenomena baru yang mungkin tidak tersentuh oleh pengusaha. Selain itu, para peneliti akan menganalisis fenomena melalui berbagai perspektif dan metode. Para peneliti mungkin dapat mengamati lebih banyak tentang hal- hal yang sekarang populer di publik, bagaimana perubahan demografis memengaruhi pasar, dan kondisi sosial orang yang memengaruhi daya beli masyarakat global.

Kemudian penulis memandang, pengusaha pada umumnya bergerak di dunia praktis, sementara sivitas akademika berkecimpung di dunia teoritis. Penulis berargumen, bahwa sivitas akademika menganalisis lebih elaboratif mengenai berbagai isu dan dinamika yang terjadi dalam pedagangan melalui pendekatan teoritis. Keduanya memiliki sudut pandang dan epistemologi yang berbeda dalam mengkaji isu. Namun keduanya dapat saling melengkapi satu sama lain. Dalam kaitannya dengan sogo shosha, keduanya dapat berkontribusi dalam mengkaji progresivitas kegiatan sogo shosha di pasar internasional dan optimalisasi strategi sogo shosha dalam bermitra dengan negara- negara berkembang. Dari sudut pandang dunia akademis, sivitas akademika akan menganalisis lebih lanjut bagaimana perilaku konsumen mempengaruhi tren pasar internasional. Penelitian juga sangat berkontribusi untuk memberikan informasi tentang pasar alternatif, tidak hanya di 
Asia Timur namun juga berbagai negara di Asia Tenggara dan kawasan-kawasan yang lebih variatif seperti Sub-Sahara Afrika, Eropa, dan Amerika Latin. Dengan demikian, sogo shosha dapat menargetkan beberapa pasar baru/non- tradisional di seluruh dunia. Di sisi lain, pengusaha sebagai pemangku kepentingan dapat memperoleh informasi baru melalui penelitian, sehingga hubungan antara pengusaha dan akademisi bersifat timbal balik. Keduanya mampu bertukar informasi aktual, wawasan menarik, dan transfer of technology untuk peningkatan yang lebih baik di setiap sisi bagi perusahaan sendiri dan juga untuk memenuhi kebutuhan pasar. Dunia usaha dan dunia pendidikan juga dapat saling bertukar SDM untuk saling bertukar wawasan. Selain itu, sogo shosha memiliki preferensi untuk merealisasikan berbagai program pertukaran bagi karyawan dengan perusahaan di wilayah lain, misalnya Asia Tenggara, Asia Timur, Uni Eropa, Amerika Serikat, Amerika Latin, dan Afrika Sub-Sahara untuk mendorong kemitraan global.

Untuk Indonesia sendiri, sudah banyak sivitas akademika di berbagai Universitas atau Lembaga Pendidikan yang bekerja sama dengan sogo shosha. Politeknik Elektronika Negeri Surabaya (PENS) juga merupakan politeknik dengan reputasi baik yang menawarkan keterampilan dalam elektronika, IT dan multimedia, dengan sedikit penekanan dalam teori pengajaran yang diseimbangkan dengan praktik praktik baik dalam laboratorium maupun magang dan keterampilan umum. Mereka menerapkan penekanan dasar seperti teori dan matematika dalam pengajaran mereka dalam hal perlunya menghadapi teknologi yang cepat berubah seperti elektronika, di mana keterampilan kejuruan dapat dengan cepat tertinggal dibanding kemajuan teknologi. Mereka memiliki beberapa pusat litbang yang berorientasi produksi di bidang tertentu seperti pusat penelitian risiko dan bencana atau pusat penelitian robotika pertanian dan pendidikan, tempat mereka melakukan penelitian mendalam, seringkali bekerjasama dengan industri dan universitas asing. Mereka juga menjalin kemitraan pengembangan institusional dengan Universitas Toyohashi Gijutsu, salah satu perguruan tinggi teknologi terapan terbaik di Jepang. Politeknik Manufaktur Bandung (Polman) memiliki reputasi yang baik sebagai institusi yang berdedikasi pada misinya dengan menerapkan konsep "pendidikan yang berorientasi produksi”, menarik industri untuk outsourcing produksi melalui kontrak. Dengan demikian, Polman dapat menciptakan lingkungan industri di workshop mereka, memberikan pengalaman industri yang berharga bagi siswa dan karyawan, serta menambah penghasilan untuk mengatasi dana pemerintah yang tidak cukup untuk membiayai operasional dan perawatan teknologi. Keahlian mereka telah diakui secara internasional; mereka memperoleh pekerjaan di Malaysia untuk membantu 
mengembangkan pendidikan yang berdasarkan produksi dan berencana bekerja dengan perguruan tinggi di Jepang untuk memperdalam keahlian mengenai teknologi pengecoran. Beberapa perguruan tinggi Jepang memulai dengan acara "hari kampus terbuka" bagi pelaku industri agar perwakilan mereka dapat diundang ke kampus untuk bertemu dengan beberapa akademisi. Seiring waktu, kebutuhan pertemuan terstruktur dapat berubah, misalnya karena topik semakin spesifik. Selain itu pertemuan akademisi atau profesional juga semakin berkembang, misalnya konferensi atau simposium, yang diikuti oleh peserta dari industri maupun akademisi (Kementerian Pendidikan dan Kebudayaan RI, 2013).

Sogo shosa seperti Sumitomo Electric memiliki divisi $R \& D$ Organization untuk mengakomodir berbagai penelitian antara perusahaan Jepang dan negara-negara mitra. Divisi tersebut memiliki beragam sub bagian, seperti $R \& D$ Planning \& Administration Division, IoT R\&D Center, Advanced Automotive Systems $R \& D$ Center, dan sebagainya. Bahkan Sumitomo Foundation memiliki program hibah terbuka setiap tahun yang dapat diikuti oleh seluruh sivitas akademika di Indonesia. Hibah tersebut juga diberikan untuk berbagai bidang ilmu, mulai dari sains, teknologi, konservasi lingkungan, industri kreatif, dan sosial humaniora (Sumitomo, 2015).

Kerjasama kampus dengan perusahaan Jepang juga dijajaki oleh Universitas Gadjah Mada (UGM) dan Komatsu Ltd. Keduanya memperkuat kerjasama dalam pengembangan dan pemanfaatan teknologi alat berat konstruksi dan pertambangan. Bentuk kerjasama tersebut direalisasikan dalam bentuk riset bersama, kuliah umum, konsultasi teknis, pelatihan dosen muda ke Komatsu, program magang mahasiswa hingga peyaluran beasiswa. Kerjasama yang dijalin akan mendorong proses pembangunan Indonesia, terutama di bidang ekonomi. Komatsu yang dikenal sebagai produsen perusahaan multinasional Jepang dan memproduksi peralatan konstruksi, pertambangan, dan militer mendukung pengembangan pendidikan dan riset di kampus UGM. Komatsu juga mendorong peningkatan kualitas SDM di Indonesia melalui kegiatan riset dan magang. Perwakilan dari Direksi Komatsu, Kawamura juga menegaskan, bahwa kerjasama dengan UGM dan beberapa perguruan tinggi di Indonesia merupakan salah satu strategi bagi Komatsu untuk memperluas jangkauan bisnis perusahaan (UGM, 2018).

Selain UGM, ITB juga gencar melakukan joint research dengan Pemerintah Jepang dan pihak industri Jepang yang direpresentasikan oleh perusahaan. Bahkan salah satu mahasiswa Fisika ITB memenangkan kompetisi Tokyo-Tech Indonesia Commitment Award 2018 (TICA) di Jepang. Kompetisi tersebut merupakan kompetisi ilmiah bagi mahasiswa S1 di Indonesia yang diselenggarakan oleh PPI Tokyo Institute of Technology, 
Tokodai. Tahun 2018, TICA mengangkat tema "Integrity to Empower the Nation" yang dilandasi oleh fenomena bonus demografi. Kompetisi karya ilmiah TICA 2018 terdiri dari empat klaster tema yaitu energy and environment, infrastructure and transportation, life sciences, dan information communication and technology. Selain TICA, ada juga program sejenis bernama "Computer Assisted Material Innovation (CAMI) 2018: Workshop dan Simposium Hasil Kerjasama Institut Teknologi Bandung dengan Mie University dalam Bidang Komputasi Material". Kegiatan ini merupakan hasil kerjasama ITB dengan Mie University, Jepang yang diikuti oleh 61 peserta dari beberapa instansi, seperti UGM, Universitas Padjajaran, Universitas Tanjungpura, STIA LAN, Universitas Telkom, UIN Sunan Gunung Jati, Universitas Negeri Malang, dan Pusat Survei Geologi (ITB, 2018).

\section{KESIMPULAN}

Diplomasi komersial Jepang melalui kehadiran dan proliferasi perusahaan multinasional Jepang di Indonesia memberikan warna tersendiri untuk peningkatan derajat hubungan diplomatik Indonesia dan Jepang. MNC Jepang atau sogo shosha telah merealisasikan berbagai proyek di sektor-sektor strategis demi mengakselerasi pembangunan Indonesia. Proyek-proyek tersebut mencakup infrastruktur, alih teknologi, pengembangan pengetahuan, serta keterampilan bagi SDM Indonesia. Kedua belah pihak menjalin kerjasama yang resiprokal dan memperoleh manfaat dari diplomasi komersial Jepang. Indonesia memperoleh investasi dari Jepang dan Jepang dapat memperluas akses pasar berbagai produk otomotif domestik ke Indonesia. Manfaat yang diterima Jepang merupakan bentuk intensi ekonomi Jepang di Indonesia. Sementara dari sisi politik, Jepang berupaya untuk memperkuat citra sebagai mitra tradisional andalan bagi Indonesia yang selalu siap membantu Indonesia.

\section{DAFTAR PUSTAKA}

\section{Buku :}

Yuniarsih, T. (2015). Komitmen Mutu. Buku Aktualisasi PNS. Jakarta: Lembaga Administrasi Negara RI.

Jurnal dan Sumber Online:

Afandi, Thohir. Siaran Pers "Bonus Demografi 2030-2040: Strategi Indonesia Terkait Ketenagakerjaan Dan Pendidikan”. Kementerian PPN/Bappenas. 22 Mei 2017, \begin{tabular}{lllll} 
diakses & pada & 24 & Juli & 2020 \\
\hline
\end{tabular} https://www.bappenas.go.id/files/9215/0397/6050/Siaran_Pers_- 
_Peer_Learning_and_Knowledge_Sharing_Workshop.pdf

Anwar, Djumadi M.. "Sogo Shosha's Business Philosophy in Indonesia". Universitas Muhammadiyah Yogyakarta. 2018, diakses pada 19 Juli 2020 pada https://www.tsukuba-g.ac.jp/library/kiyou/2018/01Djumadi\%20M.\%20Anwar.pdf

Christian, Michael \& Hidayat, Firman. "Dampak Coronavirus terhadap Ekonomi Global”. Perkembangan Ekonomi Keuangan dan Kerja Sama Internasional-Edisi I. Bank Indonesia. 2020.

“Ekonomi Kreatif Outlook 2017”. BEKRAF. 2017, diakses pada 2 Mei 2019 dari https://global.jr-central.co.jp/en/company/data-book/_pdf/2017.pdf

"Factsheet Indonesia-Japan Economic Partnership Agreement (IJEPA)". Kementerian Perdagangan RI. 2020, diakses pada 20 Juli 2020 dari http://ditjenppi.kemendag.go.id/assets/files/publikasi/doc 20180515 fact-sheetindonesia-japan-economic-partnership-agreement-ijepa1.pdf

Fukuyama, Mayumi. "Society 5.0: Aiming for a New Human-Centered Society". Japan SPOTLIGHT, diakses pada 21 Juli 2020 dari https://www.jef.or.jp/journal/pdf/220th Special Article 02.pdf

"Indonesia's Development and Japan's Cooperation: Building the Future Based on Trust". Japan International Cooperation Agency (JICA). April 2018, diakses pada 23 Juli 2020 dari https://libportal.jica.go.jp/fmi/xsl/library/public/index.html

Kartawinata, Budi Rustandi \& Wardhana, Aditya. "Marketing Strategies and Their Impact on Marketing Performance of Indonesian Ship Classification Society". International Journal of Science and Research (IJSR) Vol. 4 Issue 2. Februari 2015, diakses pada $02 \quad$ Juni 2018 dari https://www.researchgate.net/publication/327069490_Marketing_Strategies_and Their_Impact_on_Marketing_Performance_of_Indonesian_Ship_Classification_S ociety

"Laporan Informasi Intelijen Bisnis 2018: Food Preparation HS 2106". ITPC Osaka diakses pada 23 Juli 2020 dari http://itpc.or.jp/wp-content/uploads/2018/10/1.MB-Food-Preparation-HS-2106-web.pdf

Lee, Donna. "The growing influence of business in U.K. diplomacy", International Studies Perspective, Vol. 5, No 1 (2004), 50-54.

"Mahasiswa Fisika ITB Menjadi Juara di Ajang Tokyo-Tech Indonesia Commitment Award 2018 di Jepang”. Press Release ITB. 2 November 2018, diakses pada 21 Juli 2020 dari http://www.fi.itb.ac.id/2018/11/02/mahasiswa-fisika-itb-menjadijuara-di-ajang-tokyo-tech-indonesia-commitment-award-2018-di-jepang/?lang=en

Mizushima, Shigeaki. "2016 Production Forecasts for the Global Electronics and Information Technology Industries". Japan Electronics and Information Technology Industries Association (JEITA). 16 Desember 2015, diakses pada 18 Juli 2018 dari https://www.jeita.or.jp/japanese/topics/2015/1216/Epfget.pdf 
Naray, Olivier. "Commercial Diplomacy: A Conceptual Overview". Januari 2008. ResearchGate, diakses pada 24 Juli 2020 dari https://www.researchgate.net/publication/255601282 Commercial Diplomacy A _Conceptual_Overview/link/53d759a10cf21cf932c10e1e/download

"Pengembangan Strategi Kemitraan Perguruan Tinggi, Industri, dan Pemerintah di Indonesia”. Program Kemitraan untuk Pengembangan Kapasitas dan Analisis Pendidikan (ACDP). Kementerian Pendidikan dan Kebudayaan RI. 2013, diakses pada 23 Juli 2020 dari http://repositori.kemdikbud.go.id/8483/1/ACDP025\%20\%20University-Government-Industry-Partnership-Indonesia.pdf

"Perkembangan Ekonomi Indonesia dan Dunia Triwulan III Tahun 2018". Kementerian PPN/Bappenas. 27 Desember 2018, diakses pada 03 April 2019 dari https://www.bappenas.go.id/id/berita-dan-siaran-pers/perkembangan-ekonomiindonesia-dan-dunia-triwulan-iii-tahun-2018/

"Rencana Pembangunan Jangka Menengah Nasional 2020-2024: Indonesia berpenghasilan Menengah-Tinggi yang Sejahtera, Adil, dan Berkesinambungan". Kementerian PPN/Bappenas. 2020, diakses pada 24 Juli 2020 dari https://www.bappenas.go.id/files/rpjmn/Narasi\%20RPJMN\%20IV\%2020202024_Revisi\%2028\%20Juni\%202019.pdf

Ruél, Huub \& Zuidema, Lennart. "The Effectiveness of Commercial Diplomacy: A Survey among Dutch Embassies and Consulates". Netherlands Institute of International Relations 'Clingendael'. ISSN 1569-2981. Maret 2012, diakses pada 18 Juni 2020 dari

https://www.clingendael.org/sites/default/files/pdfs/20120504 cling research arti kel_discussionpaperindiplomacy_123_ruel_and_zuidema.pdf

"Spring of Integrity: An Introduction to the Sumitomo Groups Company". Sumitomo Group Public Affairs Committee. 2015, diakses pada 13 Juni 2019 pada https://www.sumitomo.gr.jp/english/act/si/pdf/01 si eweb.pdf

"UGM dan Komatsu Kolaborasi Riset". Berita UGM, diakses pada 23 Juli 2020 dari https://ugm.ac.id/id/berita/15676-ugm-dan-komatsu-kolaborasi-riset

Wibisono, Arief. "Prospek dan Tantangan Ekspor Indonesia ke Jepang". Atase Perdagangan. Kementerian Perdagangan RI. 29 Juni 2020, diakses pada http://intercafe.ipb.ac.id/wp-content/uploads/2020/06/Arief-Wibisono-BahanTayang-Webinar-Atdag-Tokyo-InterCAFE-29-Juni-2020.pdf 